\title{
POLITICAL CORRUPTION PREVENTION IN REGIONAL ELECTION AFTER THE DECISION OF THE CONSTITUTIONAL COURT NO. 33/PUU-XII/2014
}

\author{
Fajar Laksono Soeroso \\ The Constitutional Court of Republic Indonesia \\ Email: fajarlaksono@yahoo.com
}

\author{
ARTICLE INFORMATION \\ Article history: \\ Received July 28, 2015 \\ Revised November 15, 2015 \\ Accepted May 15, 2016

\section{JEL Classifications} \\ K49

\section{Key Words:} \\ Prevention, \\ Political Corruption, \\ the Constitutional Court.

\section{DOI:} \\ 10.21532/apfj.001.16.01.02.19
}

\begin{abstract}
Political dynasty in the regional election in Indonesia has been canceled by the Constitutional Court (MK). In fact, the political dynasty is considered as elements that undermine the promotion of democracy and anti-corruption culture in Indonesia. Moreover, in case of corruption, political dynasty has a very close relationship with corruption, or commonly known as political corruption. By law, a political dynasty can no longer be resisted. Therefore, what is needed is how to prevent or at least to minimize the political corruption committed by the incumbent. This paper is set in 3 subheadings, namely (a) corruption in Regional Elections: (b). Political Corruption by Incumbent; and (c) Political Corruption Prevention. Based on the analysis performed, the incumbent has broad access in economic, social, and politics which can provide a personal benefit to him or win his group in the elections. Therefore, the prevention of political corruption can be focused on (1) the financial preparedness and the control of campaign funds; (2) the opening of a space for people to demand commitment, consistency of attitude, and integrity of the incumbent in the fight against political corruption; and (3) enforcement of the rules must be carried out firmly without compromise
\end{abstract}

\section{INTRODUCTION}

Through the Decision of the Constitutional Court of the Republic of Indonesia (MK) No. 33 / PUU-XII / 2014 dated on July 8, 2015 related to the judicial review of Law No. 8 of 2015 on the Amendments to Law No. 1 of 2014 on the Election of Governor, Regent and City Mayor (Law No. 8 of 2015), the Constitutional Court (MK) is viewed to have legalized political dynasty in the 
election of Governor, Regent and City Mayor (Regional Rlection). The Constitutional Court (MK) declared unconstitutionally related to requirements of candidates for regional head / vice regional head that do not have conflict of interest with incumbent as stated in Article 7 of Law No 8 of 2015 letter r. ${ }^{1}$ In fact, the provision was intended to cut off the chains of political dynasties, corrupt actions, and abuse of authority. ${ }^{2}$ The provision was also intended to make the regional election and political contestation run fairly and equally. In order to run equally, the provision was set in such a way

$1 \quad$ In Article 7 letter r UU 8/2015 states: "tidak memiliki konflik kepentingan dengan petahana". Penjelasan Pasal 7 huruf r: "Yang dimaksud dengan "tidak memiliki konflik kepentingan dengan petahana" adalah tidak memiliki hubungan darah, ikatan perkawinan dan/atau garis keturunan 1 (satu) tingkat lurus ke atas, ke bawah, ke samping dengan petahana yaitu ayah, ibu, mertua, paman, bibi, kakak, adik, ipar, anak, menantu kecuali telah melewati jeda 1 (satu) kali masa jabatan". MK menilai, pembatasan calon kepala daerah yang memiliki hubungan dengan petahana telah melanggar UUD.» Menurut MK, tampak nyata perbedaan yang dibuat melalui ketentuan tersebut semata-mata untuk membatasi kelompok orang tertentu, yakni anggota keluarga petahana untuk menggunakan hak konstitusionalnya untuk dipilih atau mencalonkan diri. MK menilai bahwa idealnya demokrasi melibatkan sebanyak mungkin rakyat untuk turut serta dalam proses politik. Meski pembatasan dibutuhkan untuk menjamin kuota pemegang jabatan publik agar sesuai dengan kapasitas kapabilats, hal tersebut tak boleh mencegah hak konstitusi. MK menyatakan, ketentuan Pasal 7 huruf r UU 8/2015 t bertentangan dengan Pasal 28I ayat (2) UUD 1945. MK pun menyadari, dilegalkannya seseorang yang memiliki hubungan darah/perkawinan dengan petahana akan dapat membuat politik dinasti. Namun menurut MK, hal tersebut tidak boleh dijadikan alasan, terutama karena UUD 1945 mengatur supaya tidak terjadi diskriminasi.

2 See Putusan MK Nomor 33/PUU-XIII/2015, p. 76. that the incumbent is just allowed to run for the regional head in the same region for the next one period. ${ }^{3}$

It means that after the Decision of the Constitutional Court, political dynasty would still exist, whereas, political dynasty is considered as the element that undermines the promotion of democracy and anti-corruption culture in Indonesia. ${ }^{4}$ If it is linked with corruption, political dynasty is closely related to corruption. As generally understood, corruption and power are like two sides of the same coin. Corruption always accompanies a power trip. The power even becomes a catalyst for a person to have corrupt behavior. With power, someone has the authority, opportunity and influence to do anything he wants. Steven Lukes called power as the ability to manufacture influence

Ibid.

4 Dinasti politik disebut sebagai bentuk praktik politik predator. Pemahaman politik predator sendiri merupakan pengembangan tesis mengenai local strongmen yang dilakukan Migdal (1988) maupun studi Sidel mengenai local bossism (2005). Studi pendekatan ini dilakukan oleh Asako (2010) dan McCoy (1994) yang menganalisis tumbuhnya dinasti politik justru terjadi karena adanya kolusi bisnis-politik di tingkat lokal. Dalam hal ini, jejaring keluarga telah menguasai berbagai proyek pembangunan daerah yang kemudian dibagi-bagikan kepada kroni-kroninya. Dinasti politik berperan sebagai patron dalam menjaga stabilitas kolusi tersebut dengan menempatkan sanak familinya ke dalam jajaran perusahaan maupun pemerintahan. Oleh karena itu, praktik penjarahan ekonomi berlangsung secara terus menerus karena praktiknya selalu dilakukan oleh jejaring elit keluarga. Lihat Wasisto Rahardjo Jati, Revivalisme Kekuatan Familisme dalam Demokrasi: Dinasti Politik di Aras Lokal, Jurnal Sosiologi MASYARAKAT, Vol. 18, No.2, Juli 2013, Jakarta: Pusat Kajian Sosiologi, LabSosioFISIP UI, p. 206-207. 
and wealth. ${ }^{5}$ In addition, political corruption will also likely be more rampant.

There is no agreement on the conception of political corruption. J. Kristiadi says that the conception of political corruption should be adjusted with the problems and the interests of the nation in the face of the threat of political corruption. ${ }^{6}$ Arbi Sanit states that political corruption can manifest in the form of party corruption, electoral corruption, parliamentary corruption, government corruption, political justice corruption, and corruption of government bureaucracy. ${ }^{7}$ According to T. Jacob, political corruption can be in the form of tyranny of treason or subversion, lobbyism, vote-buying, electoral fraud, patronage and favoritism. ${ }^{8}$ More specifically, Ubaedillah Badrun argues that electoral corruption is as part of political corruption. Electoral corruption is a new term to describe the symptoms of corruption in the implementation of election. The term political corruption was born from a wide range of studies on the violations of campaign financing done by participants of the election, especially those with the status of incumbent.

5 Steven Lukes, "Kekuasaan", in William Outhwaite (ed), Kamus Lengkap Pemikiran Sosial Modern, Second Edition, (Jakarta: Kencana Prenada Media, 2008), p.669

6 J.Kristiadi, "Demokrasi dan Korupsi Politik", dalam Wijayanto dan Ridwan Zachrie(Ed),Korupsi Mengorupsi Indonesia, Sebab, Akibat, dan Proses Pemberantasan, (Jakarta: Gramedia Pustaka Utama, 2009), p. 448-449.

7 Arbi Sanit, Madat Korupsi Politik, Kompas, 21 Agustus 2012.

8 Bima Arya Sugiarto, "Politik Uang dan Pengaturan Dana Politik di Era Reformasi”, in Wijayanto and Ridwan Zachrie (Ed), Korupsi Mengorupsi..., Op.Cit, p. 479
Furthermore, electoral corruption is part of what being committed by politicians before getting power. ${ }^{9}$

Referring to the opinion, political corruption in this article refers to the vulnerable corruption committed by the regional head (incumbent) with various advantages possessed that could be misused for the benefit of himself (if he wants to nominate himself again), his family members, his relatives, or certain groups that are close to him. Departing from this, the legalization of political dynasty by the Constitutional Court does not need to be resisted, because what should be done right now is to accompany it using instruments of prevention or limitation.

This paper is not intended to make annotations, especially aimed at examining the decision of the Constitutional Court. This paper, however, rests on the provision that the Decision of the Constitutional Court is final and binding, that should be respected and implemented. This paper suggests a review of political corruption prevention strategies at the level of regional government as a consequence of the Decision of the Constitutional Court. So, although politically the prohibition of political dynasties is urgently needed to prevent the domination of the political power of the particular dynasty in leading a region, but legally, the Constitutional Court has 'canceled' the requirement that the candidates for regional head / vice do not have a conflict of interest

9 Ubaedillah Badrun, Membendung Korupsi Politik, Makalah dalam Seminara Mengawal Pemilu 2014 “Anak Muda Membendung Korupsi Politik 2013" held by BEMJ Sosiologi Universitas Negeri Jakarta on April 7, 2013. 
with incumbent. Therefore, the concern after the Decision of the Constitutional Court should no longer debate the substance of the decision, but rather on how political corruption by the incumbent can be prevented or at least minimized effectively.

\section{Corruption in Regional Elections}

Political corruption is viewed as the mother of corruption that becomes a major problem and the most prominent in the election. As mentioned above, electoral corruption is part of political corruption. In the literature, electoral corruption is defined as any activity undertaken by election participants and other parties who provide promising rewards in the form of money, goods, services, positions and other benefits directly or indirectly to the voters, organizers, supervisors, and other institutions related to the election aimed at influencing choice or election process thus benefiting the election participants or certain groups. Such definition can be applied not only in general elections, but also in the regional elections. This is because, historically, the regional elections, as stipulated in Law 8 of 2015, used to use the term regional head election as included in the electoral regime.

In the perspective of democracy, election is a measure of democracy. Election is the actualization of democratic values. Correspondingly, election is the actualization of democratic institutions at the local level. The term "democracy" refers to the meaning that, at the last level it is the people who give the provisions of the basic problems concerning their lives, including in assessing the state policy. Therefore, the state policy determines the life of the people. ${ }^{10}$ Through the regional election, the doors of deliberation are open wide for the people to determine the direction of governance in their region. Through the regional election, the policies made by the elected regional head are expected to meet the aspirations of the constituents. The regional elections are expected to produce local leaders who are close to people. In addition, the regional elections are an integral part of the acceleration of democratization at the national level. It means that democracy at the national level will thrive well if democratic values at the local level have been deeply rooted. ${ }^{11}$

However, as the arena of political contestation, the regional elections are often colored with political means and strategies to win the competition, including taking illegal ways, committing fraud through the abuse of power, or using the power and financial influence. It proves to the general understanding that corruption, in general, relates to power. In the political context, according to Oscar Arias Sanchez, one of the founders of Transparency International, the most dangerous corruption is an affair between the power and special interests that sneak in the power structure of government. ${ }^{12}$ Hannah Arendt, in the book

10 Deliar Noer, Pengantar ke Pemikiran Politik, CV Rajawali, Jakarta, 1983, p. 207.

11 T.A. Legowo, Menakar Kualitas Hasil Pilkada: Beberapa Pokok Catatan, Makalah Seminar Pilkada: Masalah dan Prospek, di Jakarta, 30 Agustus 2005.

12 Bima Arya Sugiarto, "Politik Uang...", Op.Cit, 
"Human Condition", also wrote that the various types of corruption are almost always related to the interaction of power. In the realm of the state, the interaction will be getting brutal when the authorities still have mentality of animal laborans, in which the orientation of the necessities of life and the obsession with production consumption is still dominant. With such mentality, politicians will tend to make politics as the main livelihood. As a result, corruption is inevitable in the interaction of political power. ${ }^{13}$

Satjipto Rahardjo introduced two types of corruption: conventional corruption and non-conventional corruption. ${ }^{14}$ Conventional corruption is corruption which refers to the Law on Corruption Eradication. There are three elements of action to be referred as corruption under the Law: (1) benefiting oneself, other people, or corporation, (2) inflicting state financial loss, and (3) violating or in contrary to law. For example, state officials accept bribes or manipulate prices in the procurement of goods / services. This confirms that corruption and procurement of goods / services cannot be separated. Where there is the procurement of goods / services, there is the corruption.

Meanwhile, non-conventional corruption is not literarily called corruption as mentioned in the Law. Thus, although an act of state official does not break the law and does not inflict the state financial loss, in a democratic system of governance, the act harms the integrity, violates

2009, p. 475.

13 Ibid.

14 Satjipto Rahardjo, Membedah Hukum Progresif, (Jakarta: Kompas, 2006), p. 135. the principles of propriety or the sensitivity of the people. Satjipto Rahardjo gave the example that non-conventional corruption is "the corruption of power", that is the implementation of public power anywhere and at any level that has evil quality, dishonesty, weak empathy, and no quality, and undermine public confidence. It is the use of arbitrary power (willekeur), sloppy, doing the job / project below standard, working carelessly, having no concern for the feelings of the people, and so on. ${ }^{15}$ Such corruption is also often referred to as pseudocorruption. Both conceptions of corruption are very likely to be found in the modes of political corruption in regional elections, because political corruption is usually committed by misusing the facilities or political convenience owned by the perpetrator. In fact, the facilities and conveniences are the people's mandate.

\section{Political Corruption by Incumbent}

Given the experience in the previous election, with regard to political corruption committed by the incumbent, it could be traced from some violations committed by the incumbent, especially based on the experience of the regional election before 2015. In general, there are at least seven cases emerging in the previous election. The seven cases are (1) political money; (2) the use of assets, state facility, and government program for the campaign; (3) the misuse of funds for political purposes; (4) the engagement / mobilization of civil servants, village heads to support a candidate; (5) the election organizer is not neutral; (6) the violation of the requirements of

15 Ibid, p. 136. 
the candidates; and (7) the loss of voting rights. ${ }^{16}$ In this regard, the Chairman of Elections Monitoring Board (Bawaslu), Muhammad, says that the incumbent has potential violations in mobilizing the bureaucracy, through the mobilization of civil servants, as well as promotion. In addition, the use of state property or the use of the regional budget is a possible potential used by the unscrupulous incumbent. ${ }^{17}$

In line with this statement, Moh. Mahfud MD recorded seven points, in which two of them are related to the incumbent. First, the regional election raises the issue of the budget. The most prominent issue is that the election uses a very high budget. Article 112 of Law No. 32 of 2004 in force at that time stated that the election fees are charged to the budget. This provision resulted in regional finances were much sucked to finance the implementation of the regional election. Thus, the budget allocation for the development, which has direct contact with the public, is reduced. In addition, the determination of the election budget often holds the election organizers. In the region where the incumbent nominate himself again, the determination and disbursement of budget are often used as a tool to pressure or as bargaining tool with the organizers of the election to smooth his candidacy or scuttle his political opponents. Second, the election triggers the politicization

16 Potensi Pelanggaran Pilkada Masih Ting $i$, http://www.pikiran-rakyat.com/ politik/2015/04/05/322411/potensi-pelanggaranpilkada-masih-tinggi. Downloaded on Juli 17 , 2015.

17 Bawaslu Antisipasi Pelanggaran Hukum Saat Pilkada, http://www.mahkamahkonstitusi. go.id/index.php?page $=$ web. Berita\&id $=11410 \#$. VbrYR7VfuSo. Downloaded on Juli 20, 2015. of the bureaucracy. In many regions, incumbent of regional head candidate almost always involves mass mobilization of civil servants, whether they are regular employees, the subdistrict heads, village heads, and others to win him over. Whereas, in democratic country, the bureaucrats should be exempt from the influence and political ties with the political forces so that the services provided by the bureaucracy to the public are neutral, impartial, and objective. Biased bureaucracy may spawn political corruption that even changes the process of regional election which is marred by improper acts.

Political corruption in regional elections not only affects the quality of the elections, but also influences the post-election political policy direction. Furthermore, political corruption in the regional elections makes the prospects of the consolidation of local democracy gloomy, resulting in the democratic consolidation delays nationwide. In the meantime, the question arises: although no democratic country is entirely free of corruption, why can corruption survive and grow in the democratic system simultaneously? ${ }^{18}$ In fact, democracy in Indonesia fails to become a system and mechanism to effectively combat corruption. The theories, explaining that democracy is a system or proper political way to eradicate corruption, are in fact inapplicable in Indonesia. Indonesia has failed to make democracy as a system and legal political tool to combat corruption. ${ }^{19}$ Political corruption is

18 Teten Masduki, Korupsi dan Demokrasi, Kompas, 24 Mei 2011.

19 Moh. Mahfud MD, Demokrasi Jalan Korupsi, Koran Sindo, March 14, 2014. 
getting worse because there is corruptio optimi pessima, in which corruption becomes very serious because it is committed by high-level officials.

\section{Political Corruption Prevention}

There are at least three factors that can be put forward as to why incumbent most likely to win the election?

First, the incumbent is in control of economic access. Position as a regent or mayor or governor makes the incumbent have a greater chance of controlling the economic access than other candidates. The ease of economic access enables the incumbent to get funds, especially to finance his candidacy. The incumbent even often gets an offer of election funds from various parties. With abundant funds, the incumbent can do many things. Even in a democratic political contestation, though it is not the only factor, funding will determine the prospects for political victory. Political funding is the main resource in capturing, maintaining, or increasing the power. ${ }^{20}$

Second, the incumbent is in control of social access. The control of social access allows the incumbent to have higher popularity and electability than other candidates. As the regional head, the incumbent has a broad access and opportunity to meet people. By using the office facilities, the incumbent is able to attend or create events to be 'close' to the citizens. In recent years, the policy of social grants in various areas could not be separated from the

20 Bima Arya Sugiarto, "Politik Uang..., 2009, Loc. Cit, p. 492. will of the incumbent to foster and strengthen social capital before competing in the elections.

Third, the incumbent is in control of political access. As a regional head, the incumbent of course has certain ease of access to the political elites, especially the leaders of political parties at the regional levels. The political parties often scramble to put the incumbent as the chairperson of the political parties at the regional level. Similarly, in the nomination before the regional election, the incumbent does not need to seek the supporting political parties because it is even the political parties that come to offer themselves as the supporters. Ease of political access will surely enable the incumbent to freely choose the political machine that he considers having significant and broad support in the region.

Based on the control of these accesses by the incumbent, the preventive measures against political corruption committed by the incumbent in the regional elections should be designed to close or at least to narrow the political corruption space in the three realms above. In this case, restrictions on the incumbent, who is in fact attached to the advantages that allow the abuse of authority, must be carried out within the limits. This is in line with the consideration of the Decision No. 33 / PUU-XIII / 2015, in which the Constitutional Court stated that ... however, such restrictions should be addressed to the incumbent of regional head and not to his family, relative, or particular groups. Since the benefits are attached to the incumbent of regional head, the possibility of the misuse is also attached to the incumbent of the regional 
head. The family of the incumbent of the regional head or specific groups might just be benefited by such a situation if there is a role or involvement of the incumbent of regional head, regardless the issue of whether the role or involvement of the incumbent of regional head is done directly and openly or indirectly and covertly. Based on such possibilities, the restrictions on incumbent of regional head should be formulated in the Act.

To narrow the political corruption committed by the incumbent in the regional elections and to prevent any political corruption in the regional elections, it is necessary to note the following:

First, in relation to the control of access to the economy by the incumbent, if the political fund is seen as the epicenter of political corruption, the regulatory regime of political corruption should be emphasized on efforts to control the flow of funds in political campaigns. Related to the campaign funds in the regional elections, Bima Arya Sugiarto mentioned two important factors: (1) the source of funding, and (2) the financial statements. In practice, the main sources of candidates' campaigns come from the candidate himself. Therefore, financial preparation is a necessary condition for the set to be a candidate. In addition to the obligation to submit the Wealth Report, the candidate can also be requested the financial profile stating factual financial readiness. Meanwhile, the financial statements related to campaign funds tend not describe the actual flow of funds. ${ }^{21}$ In other words, the campaign fund reports are still just a subterfuge. There are 6 (six) approaches used in controlling the flow of political campaign funds, namely: ${ }^{22}$

a. Limitation of campaign fund donation.

b. This limitation is intended to reduce the influence of donor to the candidate after the elections.

c. Prohibition of donations from abroad.

d. This is to reduce foreign intervention in the policy-making process after the elections.

e. Limitation of the use of campaign funds.

f. It is to limit the dependency of candidates or political parties on the donors. In addition, it is also to create a balanced political contestation among the candidates

g. Limitation of campaign time.

$\mathrm{h}$. It is intended to reduce the circulation of money during the campaign period. The longer the period of the campaign, the greater the need for the flow of money

i. Public transparency.

j. Candidates shall explain the income and expenditure to the public transparently. Thus, the public know information about the campaign funds. In addition, the media and civil society can control the candidate from the influence of the donors, and, the flow of dirty money in the circulation of campaign funds can be reduced.

k. Strengthening fund resources from the public.

1. It is intended to reduce the dependence of candidates on the individual donor or group.

\footnotetext{
21 Ibid.

22 Ibid, p. 486.
} 
Second, related to the control of social access by the incumbent, the most important thing to note is 'charismatic' politics of the incumbent who uses state facilities attached to the post. It is at this point, the space non-conventional corruption is open wide. It is true that nonconventional corruption is not a crime because it is not criminalized in the law of corruption. However, non-conventional corruption is very close to conventional corruption. Those who like committing non-conventional corruption will easily perform conventional corruption if there is an opportunity to do so. ${ }^{23}$ Voters should be aware that non-conventional corruption is a behavior that must be avoided. It is necessary to make people understand in order not to vote for a candidate who likes committing non-conventional corruption, as someday he might act corruptly in the conventional sense. Therefore, the space should be open wide for the people to demand the incumbent, as well as other candidates, to show commitment, consistency attitude, and integrity in the fight against political corruption.

Third, to narrow the political corruption by incumbent who dominates political access, Law No. 8 of 2015 has accommodated the preventive measures to narrow the space violation of the incumbent. Some considerations related to the preventive measures proposed by the Government during the discussion of the Law

23 Moh. Mahfud MD, Pemberantasan Mafia Peradilan:Mendiagnosa Akar Masalah, Menemukan Solusi Terarah, Keynote Speech pada Debat Publik dalam Rangka 10 Tahun Komisi Hukum Nasional (KHN), held by Komisi Hukum Nasional (KHN), Thursday, Februari 18, 2010 at Hotel Millenium, Jakarta.
No. 8 of 2015 in the House of Representatives, among others are: ${ }^{24}$

1. The political dynasty is set in such a way because the incumbent has access to policies and access to budget allocation, so it could give personal advantage to win the regional head election or to win his groups. In reality, most practices commonly done by the incumbent are to enlarge the grant, social aid fund, program activities directed to an attempt to win one candidate.

2. Naturally, the incumbent has a wide range of facilities and benefits attached to him, so, in carrying out his duties and functions, the facilities and benefits will attach to him constantly. For example, in many cases it can often be seen that there are many banners showing programs and activities, in which there is a picture of the incumbent or incumbent name associated with the election at the time.

3. Because he is still in office, the incumbent has the advantage of the programs and the activities which entirely or partially can be directed to win him or to win his dynasty.

4. In connection with the neutrality the civil servants, the incumbent has greater access to mobilize civil servants in order to provide favorable support to him.

Based on such things, in Law No. 8 of 2015 contains a provision that forbid the incumbent to transfer employees 6 months before the expiry of the term of office. In addition, the elected

24 Keterangan Presiden dalam persidangan tanggal 22 April 2015. See Putusan MK Nomor 33/PUUXIII/2015, p. 74-76. 
regional head is prohibited to transfer the civil servants within a period of 6 (six) months after the inauguration. The provision is intended to guarantee the neutrality of bureaucracy. The provision is based also on the fact that in relationships in society, the position between incumbent's families and other candidates is not in an equal condition. ${ }^{25}$ If the rule is clear, then it requires the strict law enforcement. In this case, the rule of law is not only characterized by the availability of legal rules, but it should be accompanied by the ability to enforce the rule of law.

Referring to the above description, the key actors in the prevention of political corruption are concentrated on the two parties: the incumbent candidates and the voters. It reminds the interesting discourse written by Guillermo O'Donnell and Philippe Schmitter. According to both of them, an important key for a successful transition period to a true democracy lies in two parties: (1) the political elite and (2) civil society, including voters. ${ }^{26}$ Political elites (leaders) are needed to run democracy well. When the political elites commit corrupt political practices, the public's distrust will increase, and therefore, the quality of democracy will be degraded. Similarly, it also needs the civil society who is capable of acting autonomously, independently, and able to be organized for concerted action.

25 Ibid.

26 See Guillermo O’Donnel \& Philippe Schmitter, Transitions from Authoritarian Rule. Tentative Conclusions about Uncertain Democracies, (Baltimore: Johns Hopkins University Press, 1986), p.19, 48.
Associated with the political elites in the context of the regional election, the candidate for regional head is required, through particular mechanism and governed by strict regulations, to have a clear commitment for the realization of a democratic society and a commitment not to perform corrupt ways in the election. At the same time, the voters, as part of civil society, have to be smart, independent and rational in voting, as well as active in monitoring. Thus the election can produce quality leader who is not oriented in pragmatic power.

The quality of the election is determined by the voters and the existence of the system covering the political corruption space. The more the number of rational and critical voters, the better the quality of the regional head chosen. The rational and critical voters are those who rationally have political awareness and can critically examine the prospective regional head, ranging from his program, vision and mission, track record, experience, and capacity of leadership, so they can think rationally before choosing. The election should also be supported by a regulatory system that closes the chances of political corruption.

\section{CONCLUSION}

Efforts to prevent political corruption in the regional elections should consider the following matters:

1. In connection with the control of access to economy by the incumbent, if the political funds is seen as the epicenter of political corruption, the regulatory regime of political corruption should be emphasized 
on the efforts to control the flow of money in political campaigns. Related to the campaign funds in the regional elections, Bima Arya Sugiarto mentioned two important factors: (1) the source of funding, and (2) the financial statements. In practice, the main sources of candidates' campaigns come from the candidate himself. Therefore, financial preparation is a necessary condition for the set to be a candidate. In addition to obligation to submit the Wealth Report, the candidate can also be requested the financial profile which states factual financial readiness.

2. Voters should be aware that nonconventional corruption is a behavior that must be avoided. It is necessary to make people understand in order not to vote for a candidate who likes committing nonconventional corruption, as someday he might act corruptly in the conventional sense. Therefore, the space should be open wide for the people to demand the incumbent, as well as other candidates, to show commitment, consistency attitude, and integrity in the fight against political corruption

3. Law No. 8 of 2015 has accommodated the preventive measures to narrow the space violation of the incumbent. If the law is clear, then it requires strict law enforcement or no compromise. In this case, the rule of law is not only characterized by the availability of legal rules, but it must be accompanied by the ability to enforce the rule of law.

\section{REFERENCES}

Deliar Noer. Pengantar ke Pemikiran Politik. Jakarta: CV Rajawali, 1983.

Guillermo O’Donnel \& Philippe Schmitter. Transitions from Authoritarian Rule. Tentative Conclusions about Uncertain Democracies . Baltimore: Johns Hopkins University Press, 1986.

Moh. Mahfud MD. Pemberantasan Mafia Peradilan:Mendiagnosa Akar Masalah, Menemukan Solusi Terarah. Keynote Speech pada Debat Publik dalam Rangka 10 Tahun Komisi Hukum Nasional (KHN), yang diselenggarakan oleh Komisi Hukum Nasional (KHN), Kamis, 18 Februari 2010 di Hotel Millenium, Jakarta . Evaluasi Pemilukada dalam

Perspektif Demokrasi dan Hukum. Ceramah Kunci dalam "Seminar Nasional Evaluasi Pemilukada: Antara Teori dan Praktik". Diselenggarakan oleh Mahkamah Konstitusi pada Rabu-Kamis, 25-26 Januari 2012 di Hotel Sultan, Jakarta.

Satjipto Rahardjo. Membedah Hukum Progresif. Jakarta: Kompas, 2006

William Outhwaite (ed). Kamus Lengkap Pemikiran Sosial Modern, Edisi Kedua. Jakarta: Kencana Prenada Media, 2008.

T.A. Legowo. Menakar Kualitas Hasil Pilkada: Beberapa Pokok Catatan, Makalah Seminar Pilkada: Masalah dan Prospek, di Jakarta, 30 Agustus 2005. 
Ubaedillah Badrun. Membendung Korupsi Politik, Makalah dalam Seminara Mengawal Pemilu 2014 "Anak Muda Membendung Korupsi Politik 2013" yang diselenggarakan BEMJ Sosiologi Universitas Negeri Jakarta pada 7 April 2013.

Wasisto Rahardjo Jati. Revivalisme Kekuatan Familisme dalam Demokrasi: Dinasti Politik di Aras Lokal. Jurnal Sosiologi MASYARAKAT, Vol. 18, No.2, Juli 2013, Jakarta: Pusat Kajian Sosiologi, LabSosio-FISIP UI.

Wijayanto dan Ridwan Zachrie (Ed). Korupsi Mengorupsi Indonesia, Sebab, Akibat, dan Proses Pemberantasan. Jakarta: Gramedia Pustaka Utama, 2009.

\section{Media and Internet Articles}

Arbi Sanit, Madat Korupsi Politik, Kompas, 21 Agustus 2012.

Bawaslu Antisipasi Pelanggaran Hukum Saat Pilkada, http://www. mahkamahkonstitusi.go.id/index. php? page $=$ web. Berita $\& i d=11410 \#$. VbrYR7VfuSo

Moh. Mahfud MD, Demokrasi Jalan Korupsi, Koran Sindo, 14 Maret 2014.

Potensi Pelanggaran Pilkada Masih Tinggi, http://www.pikiran-rakyat.com/ politik/2015/04/05/322411/potensi-pelanggaranpilkada-masih-tinggi

Teten Masduki, Korupsi dan Demokrasi, Kompas, 24 Mei 2011. 